\title{
Cutaneous Mastocytosis
}

National Cancer Institute

\section{Source}

National Cancer Institute. Cutaneous Mastocytosis. NCI Thesaurus. Code C7137.

A form of mastocytosis characterized by mast cell infiltration of the skin. (WHO, 2001) 